Marquette University

e-Publications@Marquette

School of Dentistry Faculty Research and

Publications

Dentistry, School of

$5-1-2016$

Outcomes of Primary Endodontic Therapy

Provided by Endodontic Specialists Compared with Other Providers

Jacob Burry

Marquette University

Sheila E. Stover

Marquette University

Fredrick Eichmiller

Delta Dental of Wisconsin

Pradeep Bhagavatula

Marquette University, pradeep.bhagavatula@mu.edu

Accepted version. Journal of Endodontics, Vol. 42, No. 5 (May 2016): 702-705. DOI. (C) 2016

American Association of Endodontists. Used with permission. 


\title{
Outcomes of Primary Endodontic Therapy Provided by Endodontic Specialists Compared with Other Providers
}

\author{
Jacob C. Burry \\ School of Dentistry, Department of Endodontics, \\ Marquette University, \\ Milwaukee, WI \\ Sheila Stover \\ School of Dentistry, Department of Endodontics, \\ Marquette University, \\ Milwaukee, WI \\ Frederick Eischmiller \\ School of Dentistry, Department of Clinical Services, \\ Marquette University, \\ Milwaukee, WI \\ Pradeep Bhagavatula \\ Delta Dental of Wisconsin, \\ Stevens Point, WI
}


NOT THE PUBLISHED VERSION; this is the author's final, peer-reviewed manuscript. The published version may be accessed by following the link in the citation at the bottom of the page.

\section{Abstract}

Introduction: The objective of this study was to compare the outcomes of initial nonsurgical root canal therapy for different tooth types provided by both endodontists and other providers.

Methods: By using an insurance company database, 487,476 initial nonsurgical root canal therapy procedures were followed from the time of treatment to the presence of an untoward event indicated by Current Dental Terminology codes for retreatment, apical surgery, or extraction. Population demographics were computed for provider type and tooth location. KaplanMeier survival estimates were calculated for 1, 5, and 10 years. Hazard ratios for provider type and tooth location were calculated by using the Cox proportional hazards model.

Results: The survival of all teeth collectively was $98 \%$ at 1 year, $92 \%$ at 5 years, and $86 \%$ at 10 years. Significant differences in survival on the basis of provider type were noted for molars at 5 years and for all tooth types at 10 years. The greatest difference discovered was $5 \%$ higher survival rate at 10 years for molars treated by endodontists. A hazard ratio of 1.394 was found when comparing other providers' success with that of endodontists within this 10-year molar group.

Conclusions: These findings show that survival rates of endodontically treated teeth are high at 10 years after treatment regardless of provider type. Molars treated by endodontists after 10 years have significantly higher survival rates than molars treated by non-endodontists.

Key Words: Non-surgical root canal therapy, outcomes, survival:hazard ratio, tooth-type, untoward events

Recent estimates indicate United States dentists complete more than 15 million root canal procedures annually. $\frac{1}{}$ An integral therapeutic option in the treatment and prevention of apical periodontitis, nonsurgical root canal therapy (NSRCT) has been proven to be effective in retaining teeth that would otherwise be lost. $2, \underline{3}, 4, \underline{5}, \underline{6}, \underline{z}$ Successful endodontic healing has classically been based on satisfying the criteria of reducing or eliminating apical lesions and an absence of clinical symptoms. ${ }^{-}$Even when adhering to the rigorous standard of healing, success rates of NSRCT have been shown to be 56\%-96\%. Varying study models, materials, techniques, evaluation methods, etc may be responsible for this wide variation. $3,9,10 \mathrm{~A}$ modern trend in endodontic literature has been a heavier reliance on tooth survival as

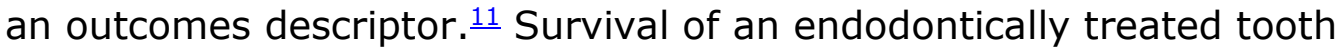
has been defined as continued presence and painless function. 11 Because of the complexities involved with deciphering outcomes of large samples, several researchers have defined success as the absence of retreatment, apical surgery, or extraction. $\underline{5}, \underline{6}, \underline{z}, \underline{12}, \underline{13}$ In composite, these additional treatments have been assigned the 
designation of untoward events and allow for more robust outcomes assessments that are based on tooth survival. $\underline{5}, \underline{6}, \underline{z}, \underline{12}, \underline{13}$

Many factors have been associated with the long-term success of endodontic therapy. These include but are not limited to the absence of an apical lesion, use of dental dams during treatment and core placement, use of surgical operating microscopes, periodontal condition, structural integrity/restorability of the tooth, biofilms, and effective post-endodontic restoration. $\underline{4}, \underline{14}, \underline{15}, \underline{16}, \underline{17}, \underline{18}, \underline{19}, \underline{20}, \underline{21}, \underline{22}$ The endodontic literature is replete with research focused on these local factors, yet few articles have been published that focus on the effect of provider training on outcomes. Alley et al 23 found that endodontic treatment provided by endodontic specialists was more than $10 \%$ more successful than treatment provided by general dentists. In a separate large-scale epidemiologic study, Lazarski et al? ${ }^{7}$ found that although endodontists on average treat cases of higher difficulty, there was no significant difference in survival rates for NSRCT provided by endodontists compared with other dental providers. This same study found that surgical endodontic therapy provided by non-endodontists failed 3 times more often than surgeries completed by endodontists. $?$ Uncertainty exists regarding how training level may impact outcomes of NSRCT as it relates to tooth type. The purpose of this study was to compare the outcomes of NSRCT provided by endodontists and nonendodontists as it relates to tooth type.

\section{Methods}

Data for this study were obtained from the electronic claims and enrollment database of Delta Dental of Wisconsin. Claims analysis was based on claims data representing 13,329,249 patient encounters between January 1, 2000 and December 31, 2013. Dental insurance claims were searched for Current Dental Terminology procedure codes D3310 (anterior NSRCT), D3320 (premolar NSRCT), and D3330 (molar NSRCT), which were considered to be triggering events. This query produced 487,476 initial NSRCT procedures performed during the 14year time period. For each of these procedures, information regarding provider type/specialty status and tooth number was collected. The title of endodontist was given only to clinicians who had completed an American Dental Association accredited U.S. endodontic residency

Journal of Endodontics, Vol 42, No. 5 (May 2016): pg. 702-705. DOI. This article is (C) Elsevier and permission has been granted for this version to appear in e-Publications@Marquette. Elsevier does not grant permission for this article to be further copied/distributed or hosted elsewhere without the express permission from Elsevier. 
program. It was decided to include all non-endodontic specialists into the broader category of other providers. As with Lazarski et al, $\underline{\underline{ }}$ success was determined by the absence of untoward events. Cases were followed and considered successful until enrollment was broken or until Current Dental Terminology codes representing extraction, retreatment, or apical surgery were encountered. Once a case met either of these 2 criteria, the case was eliminated from the sample. Cases were further subdivided into 1-, 5-, and 10-year follow-up intervals to aid in the comparison of survival over time.

\section{Analysis}

Survival estimates were computed for provider type and tooth location. Kaplan-Meier survival estimates were calculated for 1-, 5-, and 10-year survival of endodontically treated teeth. Hazard ratios for provider type and tooth type were calculated by using the Cox proportional hazards model. Analyses were performed by using SAS 9.4 (SAS Institute Inc, Cary, NC).

\section{Results}

Of the 487,476 procedures, endodontists completed 153,315 cases ( $31.5 \%$ of the total). These cases consisted of 15,832 anteriors $(10.3 \%), 27,978$ premolars (18.2\%), and 109,505 molars (71.4\%). Other providers completed 334,161 cases $(68.5 \%$ of the total). These cases consisted of 68,600 anteriors (20.5\%), 107,279 premolars $(32.1 \%)$, and 158,282 molars (47.3\%). The survival/absence of untoward events for all teeth collectively was $98 \%$ at 1 year, $92 \%$ at 5 years, and $86 \%$ at 10 years. The median follow-up time for all cases was 2.43 years.

At the 1-year interval, no significant difference in survival was noted between providers or for tooth type. Anterior teeth treated by both endodontists and other providers had 98\% survival, premolars had $99 \%$ survival, and molars survived at a rate of $98 \%$ (Table 1 ).

Journal of Endodontics, Vol 42, No. 5 (May 2016): pg. 702-705. DOI. This article is (C) Elsevier and permission has been granted for this version to appear in e-Publications@Marquette. Elsevier does not grant permission for this article to be further copied/distributed or hosted elsewhere without the express permission from Elsevier. 
NOT THE PUBLISHED VERSION; this is the author's final, peer-reviewed manuscript. The published version may be accessed by following the link in the citation at the bottom of the page.

Table 1. Summary of Survival Estimates for Endodontically Treated Teeth That Is Based on Provider Type and Tooth Type

\begin{tabular}{|c|c|c|c|c|c|c|c|}
\hline $\begin{array}{l}\text { Time } \\
\text { interval } \\
\text { group } \\
(y)\end{array}$ & $\begin{array}{l}\text { Tooth } \\
\text { type }\end{array}$ & $\begin{array}{l}\text { Provider } \\
\text { type }\end{array}$ & $\begin{array}{c}\text { Time } \\
(y)\end{array}$ & Cases & $\begin{array}{c}\text { Survival } \\
\text { distribution } \\
\text { function } \\
\text { estimate }\end{array}$ & $\begin{array}{l}\text { Lower } 95 \% \\
\text { confidence } \\
\text { limit }\end{array}$ & $\begin{array}{c}\text { Upper } 95 \% \\
\text { confidence } \\
\text { limit }\end{array}$ \\
\hline \multirow[t]{6}{*}{1} & Anterior & $\begin{array}{l}\text { Other } \\
\text { provider }\end{array}$ & 1.00 & 48,986 & 0.98 & 0.98 & 0.99 \\
\hline & & Endodontist & 1.00 & 11,354 & 0.98 & 0.98 & 0.98 \\
\hline & Premolar & $\begin{array}{l}\text { Other } \\
\text { provider }\end{array}$ & 1.00 & 77,670 & 0.99 & 0.99 & 0.99 \\
\hline & & Endodontist & 1.00 & 20,225 & 0.99 & 0.98 & 0.99 \\
\hline & Molar & $\begin{array}{l}\text { Other } \\
\text { provider }\end{array}$ & 1.00 & 113,742 & 0.98 & 0.98 & 0.98 \\
\hline & & Endodontist & 1.00 & 79,649 & 0.98 & 0.98 & 0.98 \\
\hline \multirow[t]{6}{*}{5} & Anterior & $\begin{array}{l}\text { Other } \\
\text { provider }\end{array}$ & 5.00 & 16,424 & 0.95 & 0.95 & 0.95 \\
\hline & & Endodontist & 4.90 & 3582 & 0.95 & 0.94 & 0.95 \\
\hline & Premolar & $\begin{array}{l}\text { Other } \\
\text { provider }\end{array}$ & 5.00 & 27,044 & 0.95 & 0.94 & 0.95 \\
\hline & & Endodontist & 4.99 & 6698 & 0.95 & 0.94 & 0.95 \\
\hline & Molar & $\begin{array}{l}\text { Other } \\
\text { provider }\end{array}$ & 5.00 & 38,358 & 0.91 & 0.91 & 0.91 \\
\hline & & Endodontist & 5.00 & 25,712 & 0.93 & 0.93 & 0.94 \\
\hline \multirow[t]{6}{*}{10} & Anterior & $\begin{array}{l}\text { Other } \\
\text { provider }\end{array}$ & 9.88 & 3066 & 0.91 & 0.90 & 0.91 \\
\hline & & Endodontist & 9.62 & 596 & 0.92 & 0.91 & 0.93 \\
\hline & Premolar & $\begin{array}{l}\text { Other } \\
\text { provider }\end{array}$ & 9.99 & 5475 & 0.91 & 0.90 & 0.91 \\
\hline & & Endodontist & 9.89 & 1222 & 0.90 & 0.89 & 0.91 \\
\hline & Molar & $\begin{array}{l}\text { Other } \\
\text { provider }\end{array}$ & 9.98 & 7406 & 0.84 & 0.84 & 0.85 \\
\hline & & Endodontist & 9.99 & 4605 & 0.89 & 0.89 & 0.89 \\
\hline
\end{tabular}

At the 5-year interval, no significant differences in survival were found between treated anterior teeth and premolars. Anterior teeth and premolars treated by both endodontists and other providers had a survival rate of $95 \%$. A significant difference in molar survival was discovered. Molars treated by other providers survived at a rate of $91 \%$, whereas molars treated by endodontists had a $93 \%$ survival rate $(P<.0001)$ ( Table 1$)$.

At the 10-year interval, significant differences were found for all tooth types. Anterior teeth treated by other providers survived at $91 \%$, whereas anterior teeth treated by endodontists survived at 
a rate of $92 \%(P<.0001)$. Premolar survival was $91 \%$ for other providers and $90 \%$ for endodontists $(P<.0001)$. Molar survival was $84 \%$ for other providers and $89 \%$ for endodontists $(P<.0001)$ ( Table 1 ). Figure 1 graphically portrays the $1-, 5-$, and 10 -year product limit survival estimates for each tooth and provider type.

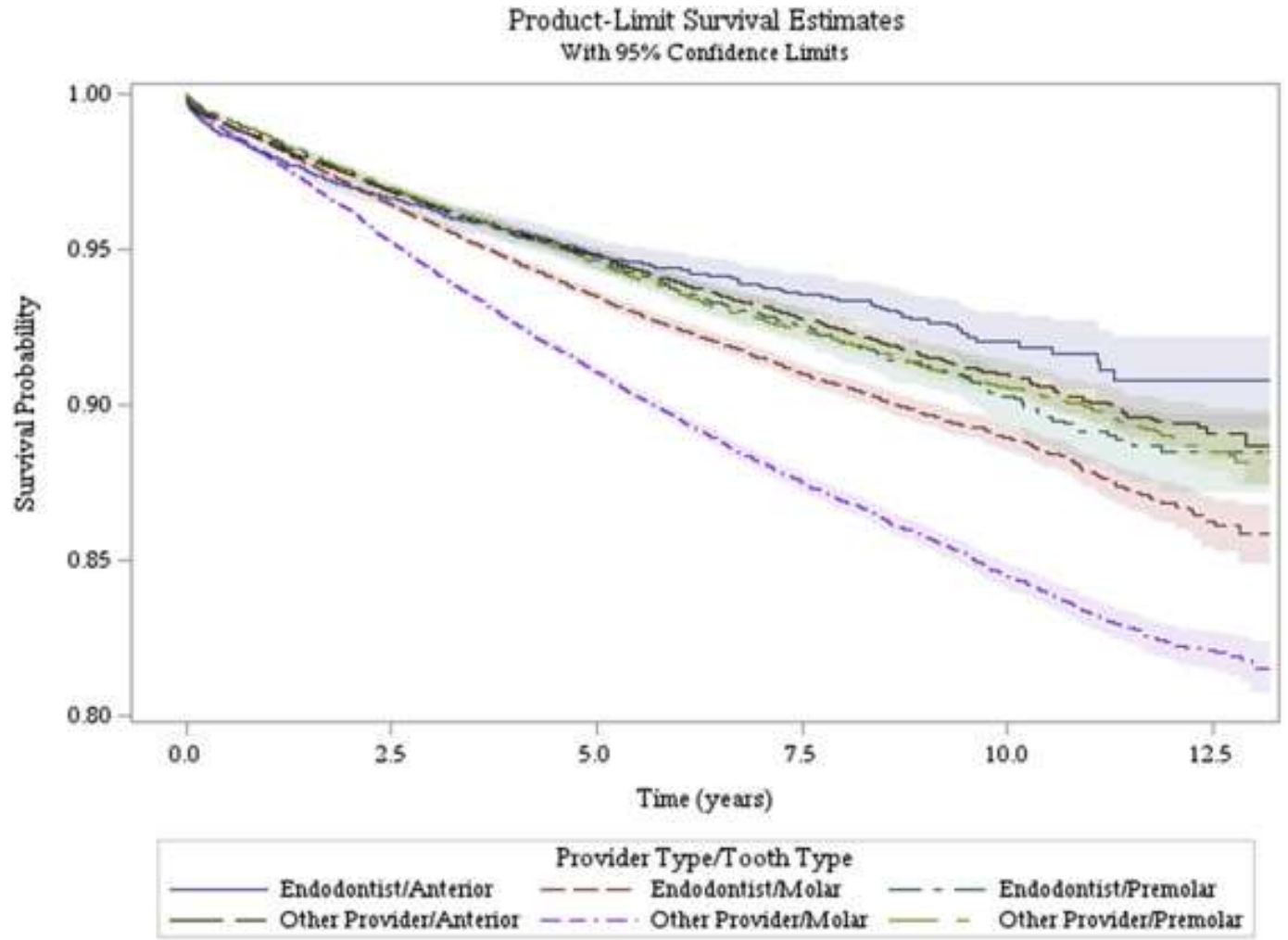

Figure 1. Product limit survival estimates of endodontically treated different tooth types treated by endodontists and other providers with $95 \%$ confidence limits.

Cox model analysis found the only significant relationship between tooth type and provider type existed for molars at 10 years. A hazard ratio of 1.394 was found when 10 -year molar survival of teeth treated by other providers was compared with the same subset of teeth treated by endodontists $(P<.0001)$.

\section{Discussion}

Survival trends of endodontically treated teeth are of considerable interest to providers, patients, and third-party payers. Endodontic therapy has proved to be a predictable and conservative method of retaining natural teeth. Large epidemiologic studies provide

Journal of Endodontics, Vol 42, No. 5 (May 2016): pg. 702-705. DOI. This article is (C) Elsevier and permission has been granted for this version to appear in e-Publications@Marquette. Elsevier does not grant permission for this article to be further copied/distributed or hosted elsewhere without the express permission from Elsevier. 
a method for assessing the outcomes of the dental health system as a whole. ${ }^{7}$ No studies to date have directly compared long-term survival rates of endodontically treated teeth as it relates to provider type and tooth type. The aim of this study was to explore this relationship.

The percentage of treatments provided by endodontists $(31.5 \%)$ and treatments provided by other providers (68.5\%) in this study closely parallel ratios seen in previous observations of 28\%:72\% and $33.9 \%: 66.1 \% . \underline{1}, \underline{7}$ The population studied was stratified to include only those patients with dental insurance. This is an important consideration because an insured patient population may present differing dental care access and expectations when compared with populations of uninsured patients. This would likely have an effect on outcomes, but to what extent is unknown. Therefore, these results should only be interpreted with respect to this population.

Use of insurance information on a scale such as that used for this project conveniently serves to minimize many sources of potential bias. At the same time, data that are limited to only procedures make important diagnostic/prognostic predictors of individual cases impossible to ascertain. $\underline{\underline{ }}$ There is no way to reliably determine preprocedural diagnosis as it relates to both the pulpal and periodontal condition of the treated patient. Restorability of the treated tooth and medical conditions that could predispose a person to endodontic failure are also not available. Final restoration and use of dental dam isolation have also been shown to have a significant impact on the long-term outcomes of endodontic treatment, but these factors cannot be adequately derived from claims data. $, \underline{5}, \underline{17}, \underline{18}, \underline{24}$

Despite the limitations of this study, the high long-term survival rates of endodontically treated teeth reconfirm the predictability of endodontic treatment provided by the dental health system as a whole. One-year, 5-year, and 10-year survival rates of 96\%, 92\%, and $86 \%$, respectively, represent survival rates similar to those of previous studies. $\underline{3}, \underline{z}, \underline{11}$ It is important to bear in mind that basing failure on untoward events yields a higher percentage of overall failure than what is actually present. The incorporation of nonsurgical retreatment and apical surgery into the criteria for failure generates a higher number of failed cases, even though these teeth are receiving adjunctive therapies that may ultimately result in tooth retention and

Journal of Endodontics, Vol 42, No. 5 (May 2016): pg. 702-705. DOI. This article is (C) Elsevier and permission has been granted for this version to appear in e-Publications@Marquette. Elsevier does not grant permission for this article to be further copied/distributed or hosted elsewhere without the express permission from Elsevier. 
function. With the high success rates of these additional modalities, the true survival rate of the sample is likely higher. It is impossible to determine to what extent by using claims data.

The large nature of the sample size in this study allowed for very small differences in survival to be determined as statistically significant between the 2 provider categories. Although several significant differences of $1 \%-2 \%$ were discovered, these small differences could be considered by some as being clinically inconsequential.

This study's finding of numerically similar survival rates between other providers and endodontic specialists at the 1-year and 5-year post-procedural periods indicates that providers of all varieties provide effective short-term and medium-term endodontic outcomes. At 10 years, anterior teeth and premolar teeth have statistically different yet numerically similar survival rates among provider types as well. However, molars treated by endodontists at 10 years show the largest difference in survival when comparing the 2 groups ( $84 \%$ other providers versus $89 \%$ endodontists). At 10 years, primary endodontic therapy provided by other providers when compared with endodontists is associated with a hazard ratio of 1.394 (95\% confidence interval, $P<.0001)$. This equates to a $39.4 \%$ higher hazard risk within this tooth population. Clinically this implies that molars treated by nonendodontists after 10 years will have a $39.4 \%$ higher likelihood of spontaneous failure when compared with molars treated by endodontists at 10 years.

In conclusion, the dental health delivery system is highly effective at providing favorable endodontic outcomes. This study has shown that endodontists and other providers have similar 1-, 5-, and 10-year survival rates for anterior and premolar teeth. Long-term survival of molars is higher when these teeth are treated by endodontists.

Future areas of research could include an evaluation of the time from completed endodontic therapy to final restoration, and whether this time period has any correlation to failure rate.

Journal of Endodontics, Vol 42, No. 5 (May 2016): pg. 702-705. DOI. This article is (C) Elsevier and permission has been granted for this version to appear in e-Publications@Marquette. Elsevier does not grant permission for this article to be further copied/distributed or hosted elsewhere without the express permission from Elsevier. 
NOT THE PUBLISHED VERSION; this is the author's final, peer-reviewed manuscript. The published version may be accessed by following the link in the citation at the bottom of the page.

\section{Acknowledgments}

The Marquette University Department of Endodontics thanks Delta Dental of Wisconsin for the provision of data used in this research and the Medical College of Wisconsin Division of Biostatistics for its statistical expertise.

The authors deny any conflicts of interest related to this study.

\section{References}

${ }^{1}$ American Dental Association Survey Center. 2005-2006 Survey of Dental Services Rendered. American Dental Association, Chicago, IL (2007)

2].G. Pak, S. Fayazi, S.N. White. Prevalence of periapical radiolucency and root canal treatment: a systematic review of cross-sectional studies. $J$ Endod, 38 (2012), pp. 1170-1176

3 S. Friedman. Prognosis of initial endodontic therapy. Endodontic Topics, 2 (2002), pp. 59-88

${ }^{4}$ C. de Chevigny, T.T. Dao, B.R. Basrani, et al. Treatment outcome in endodontics: the Toronto study: phase 4-initial treatment. J Endod, 34 (2008), pp. 258-263

${ }^{5} \mathrm{R}$. Salehrabi, I. Rotstein. Endodontic treatment outcomes in a large patient population in the USA: an epidemiological study. J Endod, 30 (2004), pp. 846-850

6s.C. Chen, L.H. Chueh, C.K. Hsiao, et al. An epidemiologic study of tooth retention after nonsurgical endodontic treatment in a large population in Taiwan. J Endod, 33 (2007), pp. 226-229

7M.P. Lazarski, W.A. Walker 3rd, C.M. Flores, et al. Epidemiological evaluation of the outcomes of nonsurgical root canal treatment in a large cohort of insured dental patients. J Endod, 27 (2001), pp. 791-796

$\underline{8} \mathrm{~L}$. Strindberg. The dependence of the results of pulp therapy on certain factors: an analytic study based on radiographic and clinical follow-up examinations. Acta Odontol Scand, 14 (Suppl 21) (1956), pp. 1-175

9 U. Sjogren, B. Hagglund, G. Sundqvist, K. Wing. Factors affecting the longterm results of endodontic treatment. J Endod, 16 (1990), pp. 498504

${ }^{10}$ G.S. Cheung. Survival of first-time nonsurgical root canal treatment performed in a dental teaching hospital. Oral Surg Oral Med Oral Pathol Oral Radiol Endod, 93 (2002), pp. 596-604

11S. Friedman, C. Mor. The success of endodontic therapy: healing and functionality. J Calif Dent Assoc, 32 (2004), pp. 493-503

12S.C. Chen, L.H. Chueh, C.K. Hsiao, et al. First untoward events and reasons for tooth extraction after nonsurgical endodontic treatment in Taiwan. J Endod, 34 (2008), pp. 671-674

Journal of Endodontics, Vol 42, No. 5 (May 2016): pg. 702-705. DOI. This article is (C) Elsevier and permission has been granted for this version to appear in e-Publications@Marquette. Elsevier does not grant permission for this article to be further copied/distributed or hosted elsewhere without the express permission from Elsevier. 
NOT THE PUBLISHED VERSION; this is the author's final, peer-reviewed manuscript. The published version may be accessed by following the link in the citation at the bottom of the page.

$\underline{13}$ M. Torabinejad, P. Anderson, J. Bader, et al. Outcomes of root canal treatment and restoration, implant-supported single crowns, fixed partial dentures, and extraction without replacement: a systematic review. J Prosthet Dent, 98 (2007), pp. 285-311

${ }^{14} \mathrm{D}$. Vire. Failure of endodontically treated teeth: classification and evaluation. J Endod, 17 (1991), pp. 338-342

$\underline{15} \mathrm{E}$. Reeh, H. Messer, D. William. Reduction in tooth stiffness as a result of endodontic and restorative procedures. J Endod, 15 (1989), pp. 512516

16D. Ricucci, J.F. Siqueira Jr. Biofilms and apical periodontitis: study of prevalence and association with clinical and histopathologic findings. $J$ Endod, 36 (2010), pp. 1277-1288

175. Aquilino, D. Caplan. Relationship between crown placement and the survival of endodontically treated teeth. J Prosthet Dent, 87 (2002), pp. 256-263

18 P.Y. Lin, S.H. Huang, H.J. Chang, L.Y. Chi. The effect of rubber dam usage on the survival rate of teeth receiving initial root canal treatment: a nationwide population-based study. J Endod, 40 (2014), pp. 17331737

19]. Goldfein, C. Speirs, M. Finkelman, R. Amato. Rubber dam use during post placement influences the success of root canal-treated teeth. J Endod, 39 (2013), pp. 1481-1484

20DD. Witherspoon, J. Small, J. Regan. Missed canal systems are the most likely basis for endodontic retreatment of molars. Tex Dent J, 130 (2013), pp. 127-139

211D. Borén, P. Jonasson, T. Kvist. Long-term survival of endodontically treated teeth at a public dental specialist clinic. J Endod, 41 (2015), pp. 176181

${ }^{22}$ T. Kvist. Endodontic retreatment: aspects of decision making and clinical outcome. Swed Dent J (Suppl 144) (2001), pp. 1-57

${ }^{23}$ B.S. Alley, G. Gray Kitchens, L.W. Alley, P.D. Eleazer. A comparison of survival of teeth following endodontic treatment performed by general dentists or by specialists. Oral Surg Oral Med Oral Pathol Oral Radiol Endod, 98 (2004), pp. 115-118

${ }^{24}$ B.M. Gillen, S.W. Looney, L.S. Gu, et al. Impact of the quality of coronal restoration versus the quality of root canal fillings on success of root canal treatment: a systematic review and meta-analysis. J Endod, 37 (2011), pp. 895-902

Address requests for reprints to Dr Sheila Stover, Department of Endodontics, Marquette University School of Dentistry, 1801 West Wisconsin Avenue, Room 320, Milwaukee, WI 53233.

Journal of Endodontics, Vol 42, No. 5 (May 2016): pg. 702-705. DOI. This article is (c) Elsevier and permission has been granted for this version to appear in e-Publications@Marquette. Elsevier does not grant permission for this article to be further copied/distributed or hosted elsewhere without the express permission from Elsevier. 